\title{
PEMAKNAAN MENOPAUSE PADA PEREMPUAN BANGSAWAN KERATON JAWA
}

\author{
Lisy Sulistiyani ${ }^{1}$, Eunike Sri Tyas Suci
}

\begin{abstract}
Background: In most cases, women experience menopause with various kind of physical and psychological symptoms. Women's understanding on menopause is influenced by their cultural background. Royal Javanese women are not sepatared from various Javanese traditions, such as "pitutur-pitutur", "laku Jawa", et cetera. Such traditions are the foundation they construct menopause experience.

Objective: The purpose of this research is to obtain the meaning of menopause as experienced by Royal Javanese Women.

Method: A qualitative method with in-depth interview is used in this research. Informants are seven Royal Javanese Women from three Javanese palaces: Solo, Yogyakarta and Cirebon; who were selected with purposive sampling technique.

Result and Discussion: Based on this research, the meaning of menopause as experienced by Royal Javanese Women is significantly influenced by their construction of Javanese culture. Menopause is understood as an important event occurred to woman's body. As an important event, Royal Javanese Women carry out several preparations and anticipative efforts prior to Menopause. Preparations are outer and inner treatment and applied in day-to-day activities such as taking Javanese traditional herbs (jamu) and carry out Javanese traditions or rituals (fasting, meditation, et cetera).

Conclusion: The Acceptance of manapausal symptoms are the result of cultural exposure and aaptation in royal live enviroments.
\end{abstract}

Keywords: Menopause, Javanese Culture, Royal Javanese Women, Meaning

\begin{abstract}
ABSTRAK
Latar Belakang: Pada umumnya perempuan mengalami menopause yang disertai dengan berbagai gejala fisik dan psikis. Pemahaman perempuan terhadap menopause dipengaruhi oleh latar belakang budayanya. Perempuan bangsawan keraton Jawa tidak terlepas dari berbagai tradisi budaya Jawa yaitu pitutur-pitutur, laku Jawa dan lain-lain. Hal ini mendasari mereka mengkonstruksi peristiwa menopause.

Tujuan: Mengeksplorasi makna manapouse menurut pengalaman perempuan bangsawan keraton Jawa Metode: Penelitian ini bertujuan untuk mengetahui gambaran pemaknaan peristiwa menopause pada perempuan bangsawan keraton Jawa. Metode yang digunakan dalampenelitian ini adalah metode kualitatif dengan menggunakan teknik wawancara mendalam. Informan terdiri dari tujuh perempuan bangsawan keraton terdiri dari tiga keraton Jawa, yakni keraton Solo, Yogyakarta dan Cirebon; yang didapatkan dengan menggunakan teknik purposive sampling.

Hasil dan Pembahasan: Berdasarkan penelitian ini pemaknaan menopause pada perempuan bangsawan keraton Jawa dipengaruhi oleh konstruksi mereka tentang budaya Jawa.

Menopause dimaknai sebagai suatu peristiwa penting yang terjadi pada tubuh perempuan. Sebagai suatu peristiwa penting, perempuan bangsawan keraton melakukan berbagai persiapan dan upaya antisipatif sebelum memasuki masa menopause. Persiapan ini meliputi perawatan lahir dan batin dan diaplikasikan
\end{abstract}

\footnotetext{
1,2 Fakultas Psikologi - Universitas Katolik Indonesia Atma Jaya
} 
dalam perilaku kehidupan sehari-hari seperti minum jamu dan melakukan laku-laku Jawa (tirakat, semedi, dan lain-lain).

Kesimpulan: Penerimaan terhadap peristiwa manapause merupakan hasil pengenalan dan penyesuaian terhadap tradisi budaya lingkungan keraton.

Kata kunci: menopause, budaya jawa, perempuan bangsawan, pemaknaan

\section{PENDAHULUAN}

Perempuan memiliki kodrat yang berbeda dengan laki-laki. Kodrat diartikan sebagai keadaan pada manusia yang dibuat Sang Pencipta. Perempuan secara kodrati akan mengalami menstruasi, kehamilan, melahirkan, menyusui dan menopause. Kodrat ini sangat berkaitan dengan sistem reproduksi perempuan. Pemahaman perempuan akan kodratnya dipengaruhi oleh latar belakang budaya dimana ia berada. Ini juga berlaku pada perempuan dengan latar belakang budaya Jawa. Sebagai salah satu budaya tertua dan mayoritas di Nusantara maka pengaruh nilai-nilai yangberlaku di dalam budaya Jawa ikut berperan di saat masyarakat mengkonstruksi peran perempuan Jawa. Budaya Jawa yang menganut sistem patriarki, merupakan sistem budaya yang mencerminkan ketidakadilan pada perempuan dengan mengkonstruksi kodrat perempuan untuk kepentingan kaum lakilaki. Konstruksi sosial yang menciptakan peran perempuan sebagai istri, ibu dan merawat anak-anak serta suami, dengan kata lain posisi perempuan adalah di rumah sebagai pengurus rumah tangga atau keluarga.

Hearty mengatakan konstruksi sosial tentang peran perempuan yang berkaitan dengan keadaan biologis tubuhnya sudah berlangsung ratusan tahun lalu, dipengaruhi oleh sistem patriarki, yang mendominasi dalam sistem sosial dan hukum di berbagai masyarakat dunia. Lebih lanjut Hearty ${ }^{1}$ menambahkan bahwa sistem patriarki merupakan sistem yang didasarkan atas sistem filsafat, sosial dan politik. Dalam sistem ini laki-laki ditempatkan sebagai sosok yang dominan, dengan kekuatan yang memiliki tekanan langsung melalui ritual, tradisi, hukum, bahasa, adat kebiasaan, etiket, pendidikan, dan pembagian kerja. Selain itu laki-laki dianggap dapat menentukan peran apa yang boleh dan tidak boleh dimainkan oleh perempuan, dan perempuan dianggap lebih rendah dari pada lakilaki. Ditegaskan oleh Beauvoir (dalam Lie,)² bahwa tugas utama perempuan adalah menjadi ibu sebab hanya perempuan yang memiliki rahim. Menjadi ibu adalah kodrat perempuan, kewajiban utama perempuan.

Saptandari ${ }^{3}$ mengatakan bahwa dalam karya sastra Jawa abad ke-18 dan ke-19 sebagian karya sastra abad ke 18 dan ke-19 berupa serat-serat piwulang yang berisi ajaran tentang moral atau nilai-nilai luhur yang dapat dijadikan pedoman dalam kehidupan secara individul dan sosial. Di antara serat-serat piwulang itu ada yang secara sengaja ditulis oleh pujangga keraton untuk kaum perempuan, seperti serat wulang putri, serat wulang estri dan serat candrarini. Pandangan-pandangan yang berisi ajaran etika dan moral untuk perempuan dalam karya tersebut memperteguh pola peran dan kedudukan yang dikonstruksikan dalam budaya Jawa, dimana perempuan diposisikan sebagai mahluk inferior yang perannya terbatas pada sektor-sektor domestik, terlukis dalam ungkapan bahwa isteri adalah kanca wingking (teman belakang), sedangkan laki-laki sebagai makhluk superior yang berperan di sektor publik. Selain itu identitas perempuan ditentukan hanya oleh fungsi biologisnya. Sudewa (dalam Susanto, 
2000) ${ }^{4}$ mengatakan bahwa dalam ajaran serat panitisastra gubahan karya sastra Jawa Kuna oleh Paku Buwono V, perempuan dihargai dari segi fungsi reproduksi dan daya tarik seksual. Pendapat tersebut menimbulkan konstruksi budaya berupa tuntutan perempuan ideal yang mencakup tiga hal yaitu perempuan harus macak (dapat tampil cantik), manak (dapat memberi keturunan), dan masak (dapat mengolah atau menyiapkan makanan) untuk suaminya.

Salah satu kodrat perempuan adalah mengalami menopause yang dianggap sebagai suatu peristiwa dimana perempuan mengalami masa berakhir fungsi reproduksinya. Pada saat itu perempuan sudah tak menghasilkan sel telur untuk dibuahi. Ini menjadi pertanda bahwa perempuan sudah tidak bisa hamil dan tentu tidak bisa juga melahirkan. Dengan berbagai keluhan fisik lainnya, maka perempuan juga mengangap dirinya tidak mampu memberikan kepuasan seksual pada pasangannya. Pada tahapan inilah perempuan sering memaknai menopause sebagai suatu momok yang menakutkan.

Menopause merupakan masa berakhirnya fungsi reproduksi perempuan, karena pada masa itu perempuan sudah tidak punya sel telur dalam uterus sehingga terjadi perubahan siklus menstruasi. Umumnya menopause dialami oleh perempuan berusia antara 45 hingga 55 tahun (Burns, et al, 2005). ${ }^{5}$ Pada sebagian budaya, ada anggapan bahwa memasuki masa menopause berarti berhentinya kehidupan seksual karena ia sudah tidak bisa hamil dan melakukan hubungan seksual. Anggapan seperti ini menimbulkan perasaan tertentu pada perempuan seperti merasa tidak berarti karena secara fisik sudah tidak menarik lagi bagi pasangannya.$^{6}$

Pada sebagian perempuan yang mengalami menopause, perubahan-perubahan fisik dan psikis kadang menjadi masalah yang sangat mengganggu, bahkan merupakan sebuah penderitaan yang menimbulkan ketidakbahagiaan. Tetapi pada sebagian perempuan justru tidak bermasalah dengan masa menopause. Seperti dalam penelitian Nosex, Kennedy dan Gudmundsdottir yang mengatakan, pada tahun 2010, ada hampir 400 juta perempuan di seluruh dunia mengalami usia menopause (45-54 tahun), banyak perempuan mengalami transisi menopause dengan mudah, beberapa dari mereka mengalami kesulitan yang menyebabkan penurunan dalam kualitas hidupnya. $^{7}$

Penulisan berbagai karya sastra yang berisi ajaran-ajarantertentumerupakanupayaantisipasi yang bisa dipelajari oleh perempuan Jawa yang hidup di lingkungan keraton untuk menghadapi perubahan tubuh dan fungsi reproduksi yang dialaminya, termasuk menopause. Ajaran-ajaran tersebut disosialisasikan secara turun temurun dari satu generasi ke generasi berikutnya. Hal ini dapat dimengerti karena pada budaya keraton Jawa, perempuan hanya dinilai dari segi daya tarik seksual dan fungsi reproduksinya, sehingga mereka berusaha untuk menjaga, merawat dan mempertahankan penampilan fisiknya. Salah satu usahanya adalah dengan menggunakan ramuan tradisional yang terbuat dari bahan alami (rempah berkhasiat) yang dikenal dengan jamu. Diperkuat oleh pendapat Soedibyo ${ }^{8}$ yang mengatakan bahwa sejak dahulu jamu digunakan untuk menanggulangi permasalahan kesehatan, selain itu dipersiapkan untuk menyongsong tahap-tahap dalam kehidupan yang dianggap penting bagi perempuan, diantaranya haid pertama, menjelang dan hari pertama melahirkan, sehabis melahirkan sampai 40 hari, dan masa menghadapi menopause. Lebih lanjut dikatakan pula bahwa putri-putri keraton sangat memperhatikan perawatan kesehatan dan kecantikan secara tradisional dengan menggunakan jamu, kosmetik tradisional dan laku (tirakat) tertentu . ${ }^{8}$ Ditambahkan pula bahwa perawatan kesehatan dan kecantikan tradisional yang secara turun-temurun diwariskan di lingkungan perempuan keraton Jawa menjadi 
bukti dari persiapan mereka saat mengalami perubahan-perubahan tertentu. Ajaran tersebut diwariskan secara menyeluruh baik aspek lahir maupun batin. Upaya ini sudah dimulai dalam tahap-tahap kehidupan perempuan, yaitu tahap menstruasi pertama sampai tahap perempuan mengalami menopause.$^{8}$

Berdasarkan uraian di atas, penulis ingin mengetahui bagaimana pemaknaan menopause pada perempuan bangsawan keraton Jawa yang mengalami menopause.

Dalam rangka mengetahui pemaknaan tersebut diatas maka landasan konseptual yang digunakan dalam penelitian ini adalah teori konstruksi sosial dari Berger \& Luckmann. Teori yang memiliki asumsi dasar: realitas merupakan hasil ciptaan manusia kreatif melalui kekuataan konstruksi sosial terhadap dunia sosial di sekelilingnya, hubungan antara pemikiran manusia dan konteks sosial tempat pemikiran itu timbul bersifat berkembang dan dilembagakan, kehidupan masyarakat itu dikonstruksi secara terus menerus, melalui tiga proses yaitu eksternalisasi, obyektivasi dan internalisasi . ${ }^{9}$

\section{METODE}

Penelitian ini menggunakan pendekatan kualitatif dalam bentuk wawancara mendalam. Wawancara menggali proses terbentuknya pemaknaankejadianmenopausepadaperempuan bangsawan keraton Jawa. Informan jumlahnya tujuh orang yang berasal dari tiga keraton Jawa yaitu Solo (Kasunanan dan Mangkunegaran), Yogyakarta (Kasultanan dan Pakualaman), dan Cirebon (Kasultanan dan Kanoman).Informan diperoleh dengan menggunakan teknik purposive sampling, dengan kriteria batasan usia 45-55 tahun, sudah menopause, dan tinggal di keraton. Data dianalisis dengan menggunakan analisis isi (content analysis).

\section{HASIL DAN PEMBAHASAN}

Penelitian ini dilakukan pada tujuh partisipan selaku perempuan bangsawan keraton Jawa yang gambaran secara lengkapnya dapat dilihat pada Tabel 1 (terlampir).

Tabel 1. Gambaran Umum Partisipan

\begin{tabular}{|c|c|c|c|c|c|c|c|}
\hline \multirow{2}{*}{ Deskripsi } & \multicolumn{7}{|c|}{ Partisipan Penelitian } \\
\hline & 1 & 2 & 3 & 4 & 5 & 6 & 7 \\
\hline Nama & AMI-SL 1 & RENI-SL 2 & YANI-SL 3 & FEBI-CRB 1 & RISA-CRB 2 & $\begin{array}{l}\text { ELI- } \\
\text { YK } 1\end{array}$ & $\begin{array}{l}\text { SRI- } \\
\text { YK } 2\end{array}$ \\
\hline Usia & 55 & 54 & 52 & 51 & 50 & 52 & 54 \\
\hline Pendidikan & S1 & SMA & S1 & S1 & SMA & S1 & SMA \\
\hline Agama & Islam & Islam & Islam & Islam & Islam & Islam & Islam \\
\hline $\begin{array}{l}\text { Status } \\
\text { Pernikahan }\end{array}$ & Menikah & Menikah & Menikah & Menikah & Menikah & Menikah & Menikah \\
\hline Jumlah anak & 2 & 2 & 3 & 3 & 2 & 2 & 2 \\
\hline Pekerjaan & $\begin{array}{c}\text { Konsultan } \\
\text { Hukum }\end{array}$ & $\begin{array}{l}\text { Ibu rumah } \\
\text { tangga }\end{array}$ & Wiraswasta & $\begin{array}{c}\text { Pegawai } \\
\text { Negeri } \\
\text { Sipil }\end{array}$ & $\begin{array}{l}\text { Ibu Rumah } \\
\text { tangga }\end{array}$ & $\begin{array}{c}\text { Pimp. } \\
\text { Organisasi } \\
\text { Wanita } \\
\text { Yogya }\end{array}$ & $\begin{array}{c}\text { Ibu } \\
\text { rumah } \\
\text { tangga }\end{array}$ \\
\hline Kota asal & Solo & Solo & Solo & Cirebon & Cirebon & Yogya & Yogya \\
\hline
\end{tabular}


Pemaknaan menopause pada perempuan bangsawan keraton Jawa merupakan hasil tiga proses secara simultan dan berkesinambungan yaitu eksternalisasi, obyektivasi dan internalisasi. Eksternalisasi merupakan adaptasi atau penyesuaian diri terhadap kebiasaan, aturan, norma, tradisi dan budaya yang berkaitan dengan kehidupan perempuan di lingkungan keraton seperti pitutur-pitutur pada saat mulai berfungsi dan berakhirnya organ reproduksi yakni pada saat menstruasi pertama (menarche) dan sebelum pernikahan serta diikuti tradisi perawatan tradisional dengan jamu. Objektivasi merupakan interaksidiri dengan dunia sosiokultural yakni kesadaran dan keyakinan diri yang didapatkan melalui proses interaksi dengan dunia sosial, yaitu lingkungan di dalam dan luar keraton yang memberikan tambahan wawasan dan informasi tentang masa berakhirnya fungsi reproduksi perempuan dengan berbagai gejala fisik dan psikis yang mungkin dialami oleh perempuan menopause. Internalisasi merupakan identifikasidiri dengan dunia sosio-kultural yakni menerima dan menyadari bahwa ia adalah perempuan yang secara kodrati akan mengalami masa berakhirnya fungsi reproduksi yang ditandai dengan berhentinya menstruasi atau mengalami menopause dengan segala dampaknya.

Ketujuh partisipan selaku perempuan bangsawan keraton yang sudah beradaptasi sejak dini dengan berbagai kebiasaan, aturan, tradisi, norma, adat istiadatdan budaya keraton seperti pitutur-pitutur saat berfungsi dan berakhirnya organ reproduksi perempuan. Hal mana disampaikan pada saat menstruasi pertama dan sebelum acara pernikahan oleh Ibu, atau eyang putri atau tante dan atau para saudara perempuan, memaknai kejadian menopause sebagai peristiwa alami, dipahami sebagai salah satu kodratnya sebagai perempuan.

Empat dari tujuh partisipan yang sejak kecil sampai dewasa tinggal di keraton memiliki penerimaan diri yang lebih menonjol. Hal ini disebabkan karena sejak kecil mereka ditempa dengan aturan-aturan keraton, melaksanakan laku-laku Jawa (tirakat, puasa, semedi dan lainlain). Selain itu mereka lebih memperhatikan tubuhnya (care) dan mempersiapkan diri dengan perawatan dan minum jamu.

Ketujuh partisipan mengalami kekhawatiran ketika akan mengalami kejadian menopause, seperti khawatir pasangan atau suami berpaling pada perempuan lain. Hal ini dilatarbelakangi oleh konstruksi budaya Jawa yang menilai perempuan dari segi fisik yaitu sisi fungsi reproduksi dan daya tarik seksual. Selain itu budaya keraton menganut poligami, yang memperbolehkan laki-laki memiliki istri lebih dari satu. Yang mana para partisipan mengalami secara langsung memiliki ibu lebih dari satu. Sosialisasi dari ibu dan eyang putri yang secara tidak langsung mempersiapkan mental dengan laku-laku Jawa dan minum jamu, sehingga mereka dapat menetralisir kekhawatiran. Selain itu berkembangnya wawasan para partisipan tentang menopause membuat mereka lebih menerima kejadian menopause.

Empat dari tujuh informan mengatakan perempuan menopause dimaknai sebagai perempuan yang sudah tua, kulit mengalami kekeringan dan mulai keriput. Hal ini disadari, diterima dan diantisipasi dengan melakukan perawatan diri, minum jamu, pasrah pada Tuhan, olahraga, selektif terhadap makanan dan tetap rutin beraktivitas atau bekerja.

Tiga dari tujuh informan memiliki keyakinan bahwa perempuan menopause di keraton mempunyai kelas tersendiri yakni dihormati dan dituakan, memiliki kualitas diri yang tinggi. Karena itu perempuan menopause dianggap sebagai panutan dan menjadi tauladan.

Tiga dari tujuh informan sejak awal tidak tinggal di keraton walaupun ketiganya merupakan 
keturunan bangsawan keraton. Namun demikian mereka tetap mengikuti dan menjalani berbagai tradisi keraton. Mereka memaknai kejadian menopause sebagai hal alami yang merupakan kodrat seorang perempuan.

Ketujuh informan tetap melakukan aktifitas saat menopause yang bertujuan menunjang pendapatan keluarga, empat dari tujuh bekerja secara penuh di luar rumah (pegawai swasta dan negeri), sedangkan tiga partisipan bekerja sambilan di rumah (buka toko kecil).

Ketujuh informan mempunyai latar belakang pendidikan yang berbeda, empat orang berpendidikan sarjana (S1), tiga orang berpendidikan SMA. Dengan pendidikan yang tinggi, partisipan lebih proaktif dalam menggali dan mencari berbagai referensi ketika mengalami menopause.

\section{KESIMPULAN DAN SARAN}

Penerimaan terhadap peristiwa menopause merupakan hasil dari proses pengenalan dan penyesuaian diri dengan tradisi dan adat istiadat budaya di lingkungan keraton. Tradisi keraton Jawa menjadi sumber utama pemahaman mereka tentang proses dimulai dan berakhirnya fungsi reproduksi perempuan dimana perempuan keraton menjalani berbagai ritual tertentu sepanjang masa kehidupannya. Berbagai tambahan pengetahuan yang didapatkan dari luar keraton juga memengaruhi terjadinya penerimaan diri tersebut. Menopause dimaknai sebagai suatu peristiwa penting yang terjadi pada tubuh perempuan. Perempuan bangsawan keraton Jawa jauh lebih memperhatikan (care) terhadap setiap perubahan yang terjadi pada tubuhnya, seperti pada saat menopause. Sebagai suatu peristiwa penting, mereka melakukan berbagai persiapan dan upaya antisipatif sebelum memasuki masa menopause. Persiapan ini meliputi persiapan lahir, batin dan diaplikasikan dalam perilaku kehidupan sehari-hari.

Faktor utama yang memengaruhi pemaknaan menopause adalah kedalaman memaknai kejadian menopause yang disertai dengan usaha untuk mempraktekan atau melakukannya dalam kehidupan pribadi. Perempuan bangsawan keraton Jawa secara rutin merawat diri, minum jamu dan melakukan laku-laku Jawa (tirakat, puasa, semedi, dan lain-lain).

\section{DAFTAR PUSTAKA}

1. Hearty, F.Keadilan Jender: PerspektifFeminis Muslim dalam Sastra Timur Tengah. Jakarta. Aksara, 2011.

2. Lie, S. Pembebasan Tubuh Perempuan: Gugatan Etis Simone de Beauvoir terhadap Budaya Patriarkat. Jakarta. PT. Gramedia, 2005

3. Saptandari, P. Beberapa Pemikiran tentang Perempuan dalam Tubuh dan Existensi. Diunduh pada 30 Juni 2015. Dari Departemen Antropologi FISIP Universitas Airlangga Surabaya, 2013.

4. Susanto,B., Sudiarja dan Praptadiharja. Citra Wanita dan Kekuasaan. Yogyakarta. PT. Kanisius, 2000.

5. Burns,A. A., Maxwell, J., Lovich, R., Shapiro, K. Bila Perempuan Tidak Ada Dokter. Panduan Perawatan Kesehatan dan Pengobatan Bagi Perempuan. Penyunting edisi Indonesia-Yogyakarta. INSIST Press, 2005.

6. Nurrachman, N. Perempuan dan Peran Ibu. Nurrachman, N. dan Bachtiar, I. (Ed.)Psikologi Perempuan: Pendekatan Kontekstual Indonesia. Jakarta: Universitas Katolik Indonesia Atma Jaya, 2011.

7. Nosex, M., Kennedy, H.P, dan Gudmundsdottir, M. Distress During the Menopause Transition, 2012. Diunduh pada 13 September 2014. Dari http:// www.Sageopen.com

8. Soedibyo, M. Alam Sumber Kesehatan. Jakarta. Balai Pustaka, 1998.

9. Berger, P. L., dan Luckman, T. Tafsir Sosial atas Kenyataan: Risalah tentang Sosiologi Pengetahuan. Jakarta. Pustaka LP3ES, 1990. 